\title{
Digitalization of tax administration communication under the effect of global megatrends of the digital age
}

\author{
Denisa Ihnatišinová ${ }^{1, *}$ \\ ${ }^{1}$ University of Economics in Bratislava, Faculty of National Economy, Department of Finance, \\ Dolnozemská cesta 1, 85235 Bratislava, Slovakia
}

\begin{abstract}
.
Research background: Digitalization of tax administration communication means the creation of paperless communication between the tax subject and the tax administration. Artificial intelligence technology creates new digital communication channels and contribute to more efficient paperless tax administration. The global trend of the digital age are digital assistants, chatbots, voicebots, respectively process automation. The growing investments in new information technologies is mainly due to the simplification of tax registration and payment, an automation of data analysis and the improvement of communication between tax subjects and tax administrations.

Purpose of the article: The aim of the article is to evaluate the impact of global megatrends of the digital age, specifically the automation of processes on changes in the communication channels of tax administration. Methods: As a research method, it is used a mix of methods combining quantitative and qualitative analysis. Specifically, the analysis of the development and current state of digital communication strategies implemented within OECD countries, comparison of digital communication methods in Slovakia and the OECD and analysis of the use artificial intelligence as a new information technology in the tax administration communication environment.

Findings \& Value added: The main findings have allowed us to highlight the global trends in terms of automation as well as new practical directions of using digital interaction in real time. The recommendation for Slovakia is the transformation to new digital technologies in communication in the tax administration, it is investing in modern technologies, especially artificial intelligence, and at the same time challenging the development of digital skills of tax administration employees in this area.
\end{abstract}

Keywords: globalization; e-Government; tax; technological change; automation

JEL Classification: $\mathrm{F} 60$; $\mathrm{H} 11 ; \mathrm{H} 20$; $\mathrm{O} 33$

\footnotetext{
* Corresponding author: denisa.ihnatisinova@euba.sk
} 


\section{Introduction}

Digitalization in the tax administration environment is part of the digital transformation of the economy, which is a priority on the global agenda of the G7, OECD, G20 and the EU to achieve inclusive and sustainable growth. The milestone of the digital transformation was 2016, from which digitalization is seen as the key to a better future, and all governments are developing policies that will facilitate the digital transformation process.

The digital economy is a complex and dynamic interconnected environment in which the flow of data has a significant impact on innovation, global value, and the world economy. Increased mobility, new ways of connecting and interdependence make it possible to create new services and business models. Society must adapt to the changes associated with digitalization; it must have the right skills to keep up with the global trends of the digital age. The starting points for the digital transformation that effect policy approaches to digitalization are grouped into four themes $[1,2]$ :

1. Internet openness and innovation - addressing the economic and social benefits of internet openness and policies that support its development. Stimulating digital innovation across the economy is essential.

2. Work and skills in the digital economy - to benefit from new, constantly evolving labour markets and new jobs in the digital age, increasing the qualifications and digital skills of the workforce. Greater use of digital technologies increases the demand for new skills.

3. Global connectivity - reaping the economic and social benefits of the development of the Internet of Things and providing the framework for tomorrow's Internet of Things. There are many opportunities to improve networks and services through the convergence of different communication technologies.

4. Confidence in the digital economy - enabling greater cooperation to protect consumers and manage their privacy and security risks. Consumer confidence is a key element in supporting the growth of the digital economy. The risk of digital security and privacy needs to be managed for economic and social prosperity.

Great and rapid development is taking place in the field of digital technologies and innovation. From a global perspective, the most important technologies today are such as artificial intelligence, the Internet of Things, 5G technology, big data and analytical data processing, cloud computing, blockchain. [3] The digital age is changing the way the economy works and brings about change in almost all areas (economy, society and education, public administration, territorial development, science, research, and innovation). In relation to financial administration, which is part of efficient public administration, processes are being digitized in the tax administration environment. Modern software solutions, online platforms and the widespread use of smart devices and the Internet enable financial administration to operate more efficiently and collect tax revenues more efficiently. New technological trends, including Ambient Intelligence, Machine Learning, Internet of Things, Cloud and Edge computing, are a major challenge for effective reform of tax administration services [4].

The digitalization of tax administration means a change in the functioning of tax administration under the effect of the extensive use of modern technologies and intelligent devices, the Internet, and the development of eGovernment. The introduction of new digital tools, practices and solutions represents an improvement in services to tax subjects while maintaining indicators of economic efficiency and a guarantee of reducing the burden on taxpayers in fulfilling their tax obligations [5]. The effects of globalization are reflected in new information technologies that affect the functioning of tax administrations. It is, for example, artificial intelligence that governments implement in their operations and in the provision of public services. According to the 2019 Artificial Intelligence Readiness Index, 
countries with strong economies, good governance and innovative private sectors dominate the top rankings. Singapore is number one in AI readiness, with the remaining 20 dominated by Western European governments, as well as Canada, Australia, New Zealand and four other Asian economies - Japan, India, the United Arab Emirates and China. There are no Latin American or African countries in the top 20. Slovakia is in 45th place out of a total of 194 monitored countries [6].

Globally, more and more countries are developing and using artificial intelligence technology. With the rapid development of tax technology, the demand for AI in the field of taxes is also growing. For multinational companies, integrating data through AI will maximize their ability to collect and analyse data and help them adapt to changing policies in tax compliance processes. In addition, automation will significantly increase the transparency of tax data, help multinational companies meet government requirements for accurate tax administrations in detail and in real time, while improving the development of government regulation [7].

Automation and technologies based on artificial intelligence, which make it possible to provide better services to taxable persons, reduce costs and increase the efficiency of tax compliance, currently play a key role. Artificial intelligence is defined as "systems that display intelligent behaviour by analysing their environment and taking action - with a degree of autonomy - to achieve specific goals" [8]. According to OECD experts, artificial intelligence is: "a machine system that is able to make predictions, recommendations or decisions affecting a real or virtual environment for a given set of goals defined by humans. It uses machine and / or human inputs to perceive a real and / or virtual environment and, by deriving a model, formulates possibilities for information or action" [9]. The area of virtual worlds is interesting for AI research, where the so-called intelligent agents. At the same time, however, virtual worlds represent a very challenging platform for AI research [10].

The Council of the European Union calls for more intensive development and deployment of artificial intelligence applications in all economic sectors to make Europe a global leader in artificial intelligence [11]. The growing importance and use of artificial intelligence and robotics in the world is also documented by the growing number of academic work on AI, which has increased up to 9 times since 1996 compared to work on computer science, which has only increased 6 times. The number of students enrolled in artificial intelligence and machine learning courses at Stanford has also increased 11 to 11 times since 1996. Similar trends can be observed at other universities. The share of jobs requiring artificial intelligence skills has increased almost fivefold since 2013 (and growth is rapid, especially in Canada and the United Kingdom). There seems to be a particularly high demand for workers with machine learning skills [12].

\section{Methodology}

The aim of the article is to evaluate the impact of global megatrends of the digital age, specifically the automation of processes on changes in the communication channels of tax administration. The object of the research are the communication channels of the tax administration within the communication with tax subjects and automation respectively artificial intelligence as a new information technology of the global age. Research questions have been identified to achieve aim:

1. What communication channels are used in tax administration and which are digitized?

2. What changes have occurred in the development of communication channels?

3. Which communication channels are affected by the global trend of automation - the use of artificial intelligence? 
Mapping of global trends in digitalization in the environment of tax administration and their subsequent summarization was carried out on the basis of studies of issues from professional, scientific and analytical materials OECD, EU and national institutions in Slovakia (Ministry of Finance, the Financial Administration) in digitalization and digital transformation of the economy, as and financial reports. Scientific articles have been prepared on the definition, meaning and impact of the use of artificial intelligence in various areas of the economy and in the tax administration environment.

The paper contains data from the implementation communication channels into tax administration in Slovakia in 2014-2019 period and across OECD countries in 2016-2017 period. The analysis of the development and current state of implementation of the communication strategy was focused on the comparison of methods of communication, while monitoring digitized as well as traditional (non-digitized) communication channels. Within the digitized channels, special attention was paid to new information technologies, namely the use of artificial intelligence as a global trend of the digital age through the analysis of the digital communication channel, resp. virtual assistant, as well as a voicebot as a replacement for call centre. As an example of best practice, the use of artificial intelligence in tax administration in Spain was explained.

The assessment of the level of digitalization of communication was carried out using the digital communication development indicator. The digital communication development indicator was calculated as a percentage change in the number of inquiries between selected years in individual types of communication channels from a national as well as an international point of view.

\section{Results and discussion}

\subsection{Digital communication strategies in the international context and the implementation of artificial intelligence in the environment of tax administration communication}

According to OECD data [13] the use of the digital communication channel continues to increase in most OECD countries, while traditional channels are declining (e. g. personal contacts have fallen by as much as $15 \%$ ). Tax subjects request information about taxes and the most used method of communication is by visiting the portal or using a mobile application and by phone. In more than 40 OECD countries, there was more than 1.6 billion in one year. incoming inquiries via the online channel and more than 300 million telephone inquiries. The methods of communication with the financial administration are listed in Table 1 [13].

Table 1. Communication channels of tax administration in OECD countries

\begin{tabular}{|c|c|c|}
\hline Channel type & $\begin{array}{c}\text { Percentage change between } \\
\mathbf{2 0 1 7} \text { and 2016 }\end{array}$ & $\begin{array}{c}\text { No. of demand (millions, } \\
\mathbf{2 0 1 7} \text { ) }\end{array}$ \\
\hline Digital assistance & $+32,5$ & 14,1 \\
\hline Email & $+19,4$ & 22,1 \\
\hline Online (websites, applications) & $+2,3$ & 1647,0 \\
\hline Paper & $-2,9$ & 65,9 \\
\hline Telephone & $-8,2$ & 327,5 \\
\hline In-person & $-15,1$ & 125,7 \\
\hline
\end{tabular}

Table 1 shows that the digitalization of information is at a high level and the importance of new digital technologies has recently increased and new tools for the communication of tax administration with tax subjects have been introduced. Digital assistants and chatbots 
come to the fore, which, in absolute terms, were the least used in 2017 (14.1 million) but recorded the highest year-on-year percentage increase $(+32.5 \%)$. The so-called Selfservice tools, such as chatbot, can resolve frequently recurring or redundant questions asked by taxpayers through traditional non-automated tax chats (FAQ-type tax questions), saving time. However, if the user's tax issue is complicated, it is possible to program chatbots to move users to human agents and provide more accurate tax advice.

Artificial intelligence brings new opportunities for financial management to develop approaches to data collection and management. In the field of taxation, as an example of the use of artificial intelligence, we can mention a voice robot respectively voicebot for call processing. Conversion of the speech of the tax subject to the text, t. j. the ability to interpret human language, process textual analysis or translation is realized through NLP (natural language processing) technology. Subsequently, a response is formulated, and a back-to-speech conversion is performed so that the tax subject hears the answer. In conjunction with the speech recognition area, which focuses on the ability to understand speech and, if necessary, translate it into text, NLP systems can be connected to speech recognition systems and provide smart chips.

Another example of the use of artificial intelligence in a digitized communication channel is a digital or virtual assistant for a specific tax area. In Spain, they introduced a virtual VAT assistant in 2017, which in the first phase of the implementation of this project focused on selected areas of VAT that were amended during the period. In Spain, in 2017 there was a change in the VAT law entitled "Immediate provision of information", which meant that many monthly VAT payers were required to submit VAT record books online. The change led to an increase in demand from taxpayers in this area, despite an extensive information campaign that included consultation with entrepreneurs, the creation of a website containing, among other things, 100 FAQs and the establishment of a new mailbox where entrepreneurs could inquire. These communication channels were not enough, so the Spanish tax administration decided to use artificial intelligence as a tool to automate information in a specific tax area. In the second phase, the virtual VAT assistant covers all areas of VAT.

Fraud detection is another way AI is useful in tax administration. AI can identify abnormalities, outliers, or deviations that require further investigation. This allows you to find problems at the beginning of the cycle before they reach a dangerous level. Social media can also be used to detect fraud, providing relevant information more quickly [14].

The use of artificial intelligence and new technologies is also reflected in the practice of various professions. Recent developments in technology have brought dramatic changes to the practice of the accounting profession. They are expected to increase their technological knowledge by accounting professionals [15]. The same trends can be expected in the financial administration professions. This means that the demand for tax-qualified IT professionals will grow and not just education and experience in the tax area will be enough.

\subsection{Digitalization of tax administration communication under the effect of artificial intelligence - case of Slovakia}

The communication strategy of the financial administration in Slovakia has changed significantly since 2014 and confirms the trends of OECD countries. Communication support is focused on information on the rights and obligations of tax subjects in matters of taxes and fees, and currently the financial administration uses the following communication lines in its communication strategy with a pro-client approach:

- provision of information through internal communication channels,

- provision of information through the media, 
- communication with the public through social networks,

- communication with the public through Taxana - machine learning chatbot,

- provision of information according to Act no. 211/2000 Coll. on free access to information.

The development of digital communication channels of financial administration has taken place since 2014, when mandatory electronic communication of selected tax entities with financial administration was introduced. This change also required changes in the approach to providing services to the public, especially through new applications, respectively. communication channels. A new call centre was opened to the public, through which information was provided not only in the field of taxes, but great attention was paid to the provision of information in the field of technical support for electronic communications. As the first state institution, the financial administration began to communicate with the public via online chat via the "Live Agent" application. The development of digital communication channels of financial management is shown in Table $2[16]$.

Table 2. Communication channels of financial administration in Slovakia

\begin{tabular}{|l|c|c|c|c|c|c|c|}
\hline & $\mathbf{2 0 1 4}$ & $\mathbf{2 0 1 5}$ & $\mathbf{2 0 1 6}$ & $\mathbf{2 0 1 7}$ & $\mathbf{2 0 1 8}$ & $\mathbf{2 0 1 9}$ & $\begin{array}{c}\text { \% change } \\
\mathbf{2 0 1 9 / 2 0 1 4}\end{array}$ \\
\hline Email & 91360 & 71381 & 75425 & 84973 & 95146 & 117597 & $+\mathbf{2 8 , 7}$ \\
\hline Call center & 197423 & 197520 & 190449 & 211365 & 223292 & 286250 & $+\mathbf{4 4 , 9}$ \\
\hline Chat & 7955 & 8474 & 5718 & 9801 & 16873 & 13531 & $+\mathbf{7 0 , 0}$ \\
\hline $\begin{array}{l}\text { Processed materials for } \\
\text { media }\end{array}$ & 90 & 109 & 48 & 52 & 42 & 29 & $\mathbf{- 3 2 , 2}$ \\
\hline $\begin{array}{l}\text { Information materials on } \\
\text { the website }\end{array}$ & 76 & 82 & 83 & 93 & 108 & 76 & $\mathbf{x}$ \\
\hline Sum & $\mathbf{2 9 6 9 0 4}$ & $\mathbf{2 7 7 5 6 6}$ & $\mathbf{2 7 1 ~ 7 2 3}$ & $\mathbf{3 0 6 ~ 1 3 9}$ & $\mathbf{3 3 5 4 6 1}$ & $\mathbf{4 1 7 4 8 3}$ & $+\mathbf{4 0 , 6}$ \\
\hline
\end{tabular}

Table 2 shows that the digitalization of information in the form of digital communication channels in Slovakia has been constantly increasing since 2014. The most widespread communication channels are call center, e - mail communication and chat. Demands from tax subjects increased by $40 \%$ between 2019 and 2014 . The social network is also an important communication channel. The financial administration has been operating the Facebook page since 2012.

In 2018, the financial administration launched an automated chatbot called TAXANA on the financial administration portal and messenger on the social network Facebook, whose task is automatic communication between the public and the institution, which allows the financial administration to handle more inquiries and relieve call center employees. In 2019, there was a significant expansion of the automated chatbot with the aim of automating and increasing the availability of financial administration for its clients. During 2019, 113,989 people communicated with Taxana. The most inquired topics were tax returns, electronic cash register, income tax, VAT. The automatic chatbot Taxana thus becomes a full-fledged communication channel.

The Financial Administration of the Slovak Republic currently consists of state administration bodies in taxes, fees and customs: The Financial Directorate of the Slovak Republic, tax offices, customs offices and the Financial Administration Criminal Office. However, tax administration is also performed by self-government bodies, it is municipalities that are part of the implementation of eGovernment at the local level. The municipality, as a basic element of territorial self-government, gained through the process of decentralization the tax autonomy necessary for the exercise of self-government powers, the development of the territory and the satisfaction of the needs of its inhabitants [17]. Therefore, from the point of view of digitalization, municipalities should also introduce 
new digital technologies in their communication with the population who are in the position of tax subjects of local taxes.

\subsection{Discussion - threats and risks of new digital technologies}

Global technological trends also reflected in eGovernment, such as artificial intelligence, allow processes and decisions in public administration to be implemented much more efficiently and with lower risks through the availability of quality and relevant data at the right time and predictive tools whose intelligence has increased recently. On the other hand, the negative effects of digital technologies on society need to be mitigated, such as cyber threats, threats to human jobs and the risks of low digital skills. At present, the threats, and risks of the introduction of new digital technologies, especially artificial intelligence, are a large area of research $[18,19]$. Artificial intelligence is likely to be overestimated in many respects in terms of impact on society. An increasing number of studies claim that the consequences for the labour market will be very uneven and will depend on many factors, including the level of education and gender [20].

Automation in general means that robots take on more and more routine tasks and remove workers from some jobs. At the same time, workers in other jobs can use increasingly sophisticated technology to help them perform their tasks better. In this area, countries need to focus on improving the skills of workers whose jobs are at high risk of automation. For workers to thrive in the digital workplace, they need a wide range of skills - strong cognitive and socio-emotional skills, as well as digital skills. The subject of research is also the effect of new technologies on the redundancy of the workforce and at the same time the effect of automation of tasks previously performed by the workforce on the creation of new versions of existing tasks in which work has a comparative advantage. Research points to the fact that automation reduces employment and labour force share and may even reduce wages, while the creation of new tasks and positions resulting from automation has the opposite effect [21].

The OECD report on skills in the digital world [22] draws attention to the risks of digitalization in the form of deepening regional disparities within or between countries. It also provides the best ways to overcome these risks. To make the best use of digitalisation, the OECD recommends that countries put in place a comprehensive package that coordinates education, labour market, taxation, housing, social protection and research and innovation policies. Skills and training policies must be a cornerstone of such a package and are essential to ensure that the digital transformation contributes to inclusive growth.

Although robots will not completely replace the human workforce in the short term, the issue of labour dislocation needs to be addressed through targeted policies, as global technological trends have a negative impact on the polarization of employment and wealth in countries. Robotization is growing faster than the ability of workers to acquire new skills [23]. However, concerns that artificial intelligence will eventually replace human workers throughout the economy are not necessary. Although AI will radically change the way it works and its performer, it will have a greater impact on this technology to complement and expand human capabilities, not to replace them. A survey of 1,500 companies found that companies achieve the most significant performance improvements when people and machines work together [24]. The complementarity of people and $\mathrm{Al}$ means that each can bring its own strength in the decision-making processes in an organization, which are typically characterized by uncertainty, complexity, and ambiguity. With more computing power to process information and an analytical approach, Al can expand a person's knowledge of complexity, while people can still offer a more holistic and intuitive approach to dealing with uncertainty and ambiguity in organizational decisions. This assumption 
reflects the idea of expanding intelligence, which states that Al systems should be designed with the intention of expanding, not replacing, human contributions [25].

\section{Conclusion}

Demands for information from tax entities and the extent of communication are mainly affected by changes in taxation and the introduction of new tools for effective tax collection. Increasing demands for quality communication with the financial administration in Slovakia are related to new digital projects that increase the efficiency of tax collection, i.e. with the gradual expansion of mandatory electronic communication in the years 20142018 and in 2019 with the introduction of online connection of cash registers to the financial administration, respectively with the implementation of the digital project eKasa (online cash register). A great advantage for tax subjects is the development of digital applications and channels in the period 2014-2019, which reduce the administrative burden and increase the awareness of tax subjects about changes. The most used methods of communication are currently chat (increase by $70 \%$ ), mail communication (increase by 45 $\%$ ) and call center (increase by $28 \%$ ).

Recommendations for Slovakia based on foreign experience relate to greater investment in new digital information technologies, specifically in the automation of processes in communication with tax entities. Although Slovakia has been using artificial intelligence in the communication channel since 2018, the so-called chatbot, in an international comparison it is insufficient. Rapidly evolving new information technologies come to the fore, namely the use of artificial intelligence in the form of voicebots or virtual assistants for specific tax areas. Within OECD countries, the use of artificial intelligence in communication increased by up to $32.5 \%$ and traditional telephone communication with the use of employees decreased by $8 \%$. The mentioned technology - artificial intelligence can thus be unambiguously described as a global megatrend of the digital age, which will affect the functioning of financial administration worldwide.

The challenge for Slovakia is to modernise public administration in the context of the country's digital transformation and to effectively collect taxes, reduce the administrative burden on entities and voluntarily meet tax obligations to develop a new financial administration strategy for the near future and continue to meet the goal of paperless financial administration. The main tools are digital technologies, especially artificial intelligence, data-driven state, the Internet of Things, the use of which is also referred to as the global megatrends of the digital age. A priority area should also be the development of digital skills for financial administration staff and the upgrading of skills for jobs that are affected by automation.

The acknowledgements of this paper is an output of the research project supported by the Grant Agency of the Ministry of Education of the Slovak Republic and the Slovak Academy of Sciences (VEGA) No. 1/0779/19 Výzvy digitalizácie ekonomiky pre oblast' zdaňovania, možné riešenia a ich predpoklady (Challenges of digitalisation of the economy for taxation, possible solutions and their assumptions).

\section{References}

1. OECD. (2016). Digital Economy: Innovation, Growth and Social Prosperity. OECD Ministerial Meeting - Cancún, Mexico, 21-23 June 2016. Retrieved from: http://www.oecd.org/internet/ministerial/STI-Cancun-2016-ENG.pdf 
2. OECD. (2017). Digital Economy Outlok 2017. Retrieved from: https://espas.secure.europarl.europa.eu/orbis/sites/default/files/generated/document/en/ 9317011e.pdf

3. ÚPVII. (2019). Stratégia digitálnej transformácie Slovenska 2030. Retrieved from: https://www.mirri.gov.sk/wp-content/uploads/2019/06/Strategia-digitalnejtransformacie-Slovenska-2030.pdf

4. Çetin Gerger, G. (2019). Tax Services and Tax Service Providers' Changing Role in the IoT and AmI Environment: Principles, Technologies, and Applications. In Guide to Ambient Intelligence in the IoT Environment. Springer International Publishing.

5. Li, J., Bao, N.J., Hu, S., Hu, W., Zerbino, M. (2020). Digitization and International Tax Dispute Resolution: A Window of Opportunity for BRITACOM. SSRN Electronic Journal. Osgoode Legal Studies Research Paper. Retrieved from: doi:10.2139/ssrn.3664039

6. Oxford insights. (2019). Government Artificial Intelligence Readiness Index 2019. Retrieved from: https://ai4d.ai/wp-content/uploads/2019/05/ai-gov-readinessreport_v08.pdf

7. Huang, Z. (2018). Discussion on the Development of Artificial Intelligence in Taxation. American Journal of Industrial and Business Management, 08(08), 1817 1824.

8. European Commission. (2019). TRUSTWORTHY AI. Joining efforts for strategic leadership and societal prosperity. Retrieved from: https://ec.europa.eu/digital-singlemarket/en/news/trustworthy-ai-brochure

9. OECD. (2019). Artificial Intelligence in Society. OECD Publishing, Paris. Retrieved from: https://doi.org/10.1787/eedfee77-en

10. Petrovic, V. M. (2018). Artificial Intelligence and Virtual Worlds - Toward HumanLevel AI Agents. IEEE Access, 6, 39976-39988.

11. Rada EÚ. (2019). Umelá inteligencia - Závery o koordinovanom pláne v oblasti umelej inteligencie. Retrieved from: https://data.consilium.europa.eu/doc/document/ST-61772019-INIT/sk/pdf

12. Furman, J., Seamans, R. (2019). AI and the Economy. Innovation Policy and the Economy, 19(1), 161-191.

13. OECD. (2019). Tax Administration 2019: Comparative Information on OECD and other Advanced and Emerging Economies. OECD Publishing, Paris. Retrieved from: https://doi.org/10.1787/74d162b6-en.

14. Xiong, F., Chapple, L., Yin, H. (2018). The use of social media to detect corporate fraud: A case study approach. Business Horizons, 61(4), 623-633.

15. Zhang, Y., Xiong, F., Xie, Y., Fan, X., Gu, H. (2020). The Impact of Artificial Intelligence and Blockchain on the Accounting Profession. IEEE Access, 8, 110461110477.

16. Financial Administration of Slovak Republic. (2014-2019). Výročné správy za roky $2014 a \check{z}$ 2019. Retrieved from: https:/www.financnasprava.sk/sk/financnasprava/vyrocne-spravy

17. Belkovicsová, D. (2019). Špecifické finančné vzt’ahy v rámci územnej samosprávy v SR. Finančné trhy: vedecký časopis = Scientific Journal, 16(2), 1-16.

18. Huang, M-H, Rust, R. T. (2018). Artificial Intelligence in Service. Journal of Service Research, 21(2), 155-172. 
19. Frank, M. R. et al. (2019). Toward understanding the impact of artificial intelligence on labor. Proceedings of the National Academy of Sciences of the United States of America, 116(14), 6531-6539.

20. Clifton, J., Glasmeier, A., Gray, M. (2020). When machines think for us: the consequences for work and place. Cambridge Journal of Regions, Economy and Society, 13(1), 3-23.

21. Acemoglu, D., Restrepo, P. (2018). The Race between Man and Machine: Implications of Technology for Growth, Factor Shares, and Employment. American Economic Review, 108(6), 1488-1542.

22. OECD. (2019). OECD Skills Outlok 2019: Thriving in a Digital World. OECD Publishing, Paris. Retrieved from: https://doi.org/10.1787/df80bc12-sk

23. Gentili, A., Compagnucci, F., Gallegati, M., Valentini, E. (2020). Are machines stealing our jobs?. Cambridge Journal of Regions, Economy and Society, 13(1), 153173.

24. Wilson, J. H, Daugherty, P. R. (2018). Collaborative Intelligence Humans and AI Are Joining Forces. Harvard Business Review, 96(4), 115-123.

25. Jarrahi, M. H. (2018). Artificial intelligence and the future of work: Human-Al symbiosis in organizational decision making. Business Horizons, 61(4), 577-586. 